\title{
Soma and Haoma: Ayahuasca analogues from the Late Bronze Age
}

\author{
MATTHEW CLARK*
}

School of Oriental and African Studies (SOAS), Department of Languages, Cultures and Linguistics, University of London, London, UK

(Received: October 19, 2018; accepted: March 14, 2019)

\begin{abstract}
In this article, the origins of the cult of the ritual drink known as soma/haoma are explored. Various shortcomings of the main botanical candidates that have so far been proposed for this so-called "nectar of immortality" are assessed. Attention is brought to a variety of plants identified as soma/haoma in ancient Asian literature. Some of these plants are included in complex formulas and are sources of dimethyl tryptamine, monoamine oxidase inhibitors, and other psychedelic substances. It is suggested that through trial and error the same kinds of formulas that are used to make ayahuasca in South America were developed in antiquity in Central Asia and that the knowledge of the psychoactive properties of certain plants spreads through migrants from Central Asia to Persia and India. This article summarizes the main arguments for the botanical identity of soma/haoma, which is presented in my book, The Tawny One: Soma, Haoma and Ayahuasca (Muswell Hill Press, London/New York). However, in this article, all the topics dealt with in that publication, such as the possible ingredients of the potion used in Greek mystery rites, an extensive discussion of cannabis, or criteria that we might use to demarcate non-ordinary states of consciousness, have not been elaborated.
\end{abstract}

Keywords: psychedelics, ayahuasca, Vedas, Avesta, soma, haoma

\section{THE ORIGINS OF THE SOMA/HAOMA CULT}

The soma/haoma drink and the cult of a sacred fire are the central elements of the religious practices of both the Brahmans of South Asia and of Zoroastrianism (Bowman, 1970, p. 7; Boyce, 1975, p. 176; Malandra, 1983, p. 150; Watkins, 1978 , p. 13), which was the main religion of pre-Islamic Persia. The term soma derives, according to most but not all commentators, from the Sanskrit root $\sqrt{ } s u$, meaning a juice that has been pressed out or expressed. Similarly, the same derivation applies to the term haoma (from the root $\sqrt{ } h u$ ) in the Avestan language of the sacred texts (the Avesta) of Zoroastrians. Soma/haoma thus refers to the extracted juice of a plant (or plants) used in Indo-Iranian religious rituals and not to any plant in particular.

Over a century ago, it was noticed by scholars of Asian religions, such as Macdonell (1995 [1898], pp. 113-114), that there were many similarities and homologies in the practices, language, and mythology of Zoroastrianism and Vedic religion, represented in the Vedas, the sacred texts of the Brahmans of South Asia. Many names of people and deities in the myths associated with soma in the Vedic tradition are very similar or almost identical with characters associated with haoma in the Avesta. In addition, central to both traditional Vedic religion and Zoroastrianism is the sacrifice of animals during important rituals. The language of the oldest parts of the Avesta is written in an archaic language known as old Avestan, which is very close in many respects to the Vedic Sanskrit used in the compilation of the earliest portions of the Vedas. Several scholars have explored linguistic evidence that indicates an original, common source for several words used in ancient Central Asian religion, such as amśs (anću), an early term for soma, and
Indra, one of the main deities of Vedic religion (Parpola, 2015, p. 66; Thompson, 2007, p. 67; Witzel, 2003, p. 36ff.).

The close connections between ancient Zoroastrianism and Vedic religion, which has been comprehensively explored by scholars over the last century, have led to the almost universally accepted consensus that Zoroastrianism and Vedic religion had a common origin, which was the upper-Oxus region of Turkmenistan (Parpola, 2015, pp. 35-106). Migrations of people from Central Asia around 1600 BCE resulted in the cult of soma/haoma being transmitted to both Persia, where it formed a central constituent of Zoroastrianism, and to South Asia, in the form of Vedic religion.

\section{TRANSMISSION OF THE SOMA/HAOMA CULT TO PERSIA AND INDIA}

Around $1615 \mathrm{BCE}$, there was a massive eruption of the volcanic mountain in the midst of the Santorini islands, which lie around $110 \mathrm{~km}$ north of the island of Crete in the Mediterranean. This was the largest explosion on earth since the last ice age, about 10,000 years ago. Ejecta fell $200 \mathrm{~km}$ from the epicenter, the tsunami went twice around the world, aborigines heard the explosion in Alice Springs in Australia, up to 7 in. of volcanic ash covered the ground in South Africa, and the skies went dark in China for 7 years, causing crop failure and famine (Friedrich, 2009).

\footnotetext{
* Corresponding address: Matthew Clark; Research Associate; School of Oriental and African Studies (SOAS), Department of Languages, Cultures and Linguistics, University of London, 10 Thornhaugh Street, Bloomsbury, London WC1H 0XG, UK; Phone: +44 207637 2388; E-mail: matt@mahabongo.com
}

This is an open-access article distributed under the terms of the Creative Commons Attribution-NonCommercial 4.0 International License, which permits unrestricted use, distribution, and reproduction in any medium for non-commercial purposes, provided the original author and source are credited, a link to the CC License is provided, and changes - if any - are indicated. 
People would have moved around as a consequence of the volcanic catastrophe, looking for food and sustenance. About 1600 BCE was also the time of the collapse of all the highly developed, late Bonze Age city-states, which stretched from the Mediterranean to India. It is now believed that these city-states knew about each other, and various artifacts such as jewelry and pottery items found at different sites illustrate that there was also trade between them (Possehl, 2002; Sarianidi, 1999; Witzel, 2003, p. 31).

The migrations of people around Asia and the sudden decline of the Bronze Age city-states around $1600 \mathrm{BCE}$ have been commented on by numerous scholars but no specific, overall cause has so far been invoked. Witzel (2000, p. 290) remarks "The sudden decline of all cultures of the area, from Mesopotamia to the Indus and from Bactria to Bahrain and Oman, cannot simply be explained by an invasion of Aryan hordes'." What has been overlooked to date in the research into migration and the decline of the Bronze Age city-states in Asia around $1600 \mathrm{BCE}$ is the significance of the eruption of the Santorini volcano. Although the sudden demise of the Minoan civilization on Crete is now recognized as a consequence of the eruption of the Santorini volcano (Friedrich, 2009), the non-violent collapse of the Indus Valley civilization, which probably at its peak numbered around a million people, has never been satisfactorily explained; various theories have been proposed, including climate change or flooding, as possible causes (see, e.g., Flood, 1996, p. 30). It seems probable that the collapse of the Indus Valley culture was also due to the eruption of the volcano and the interruption of administration, trade, and supply routes.

Another of the Bronze Age centers of civilization that collapsed quite quickly around this time (1600 BCE) was the so-called Bactria-Margiana Archeological Complex - also known as the Oxus civilization - in Turkmenistan. It flourished from c. 2200 and $1700 \mathrm{BCE}$, and it is from this region that migrants either adopted or took the soma/haoma cult. The Russian archeologist Victor Sarianidi, who undertook extensive research in Turkmenistan and Afghanistan from the mid1970s for around 40 years $(1994,1999,2003,2007)$, found in Gonur "Temenos" and nearby sites (known as Togolok 1 and Togolok 21) large vats that appear to have been used for storing pressed plant juices (soma/haoma). Pressing stones, mortars, grinders, ceramic strainers, and vats with perforated bottoms were discovered. Tests on remains of these vats indicated the presence of opium, cannabis, and ephedra, although these findings were challenged several years later (see Clark, 2017, pp. 114-115 for further details).

Sarianidi's response to the negative results from subsequent tests (1999, pp. 309-310) is that they were conducted 5 years after the original tests, after the vats had been exposed to the rain and the sun, and that the remains may have eroded. The original tests led Sarianidi (1994, p. 388) to believe that ephedra, which contains ephedrine, a stimulant with an effect similar to that of coffee or adrenaline, was the original haoma (or an ingredient of haoma). However, it needs to be clarified that phytochemical tests are specific: they are for particular substances. There may have been all kinds of other plants used in the concoctions that they were making but we do not know at the moment exactly, which plants may have been used for making soma/haoma.

\section{SOMA/HAOMA CULTS OF ASIA}

Around 1600 BCE, people calling themselves Ārya first arrived in what is currently the Punjab region of India/ Pakistan, having migrated from the Turkmenistan region of Central Asia. The origins of these people were initially established through archeological and linguistic research (Witzel, 2000); this has recently been confirmed through genetic studies (Joseph, 2017). These Āryan migrants, who did not number more than a thousand or two when they first arrived in South Asia, did not construct permanent buildings for many centuries. They spoke Vedic Sanskrit, which is an older form of classical Sanskrit; had excellent horses and chariots; loved cows; and often engaged in battle.

As noted previously, these migrants to South Asia brought with them Vedic religion, which included the Central Asian cult of the sacred fire, some of their deities (such as Indra), and the cult of drinking soma. In the ritual world of the Brahmans - which became the collective name of the priests of this tradition in South Asia - there are dozens of rituals known as sacrifices (yāga/yajña). Dandekar (1958-1962) provides details of around 160 Vedic śrauta rituals, which are those performed in a communal arena. The most important and esteemed of these rituals entail the making and drinking of soma juice (soma rasa) (Hillebrandt, 1980, Vol. 1:131ff.; Kane, 1997, Vol. 2, Part 2, pp. 1174-1204; Mahadevan \& Staal, 2003), which complex of practices are core tropes of Hindu mythology.

The haoma cult that was transmitted to Persia by migrants from Central Asia was integral not only to Zoroastrianism but also to the later cult of Mithras, which, from the latter part of the first millennium BCE until the early centuries CE, stretched from North Africa to Scotland, and was almost as widespread as Christianity. It was a cult particularly popular with soldiers and the military. Bowman (1970) examines a body of Aramaic inscriptions on mortars and pestles (mostly made of green chert) and plates found in Persepolis, dated to the 5th century BCE, many inscribed during the reign of Artaxerxes 1 (r. 465-425 BCE). Haoma was drunk at Mithraic festivals and was used in Persepolis in Iran in the Achaemenid period at least from the time of Xerxes (r. 486-465 BCE) (Bedrosian, 2000; Bowman, 1970, p. 8ff.).

There was also a branch of Scythians (Sakā) known as haomavarga (haoma twisters). These fierce, horse-riding nomads roamed Central Asia, from southern Russia to eastern China, between about the 9th century BCE and 4th century CE (Abaev, 1975, p. 2; Bartholomae, 1904, p. 1735; Gershevitch, 1974, pp. 4-5). The Scythians also liked to intoxicate themselves with cannabis. Herodotus (1968, pp. 265-266) famously reports (in the 5th century BCE) Scythians inhaling smoke from cannabis seeds (buds) placed on braziers inside small tents and howling with laughter.

It is also suggested (Clark, 2017, Chapters 16-17) that the Greek potion kykeōn (mixed potion), which in one form was administered in mystery rites at Eleusis $(20 \mathrm{~km}$ west of Athens) and elsewhere, was most probably based on formulas similar to those used for soma and haoma. 


\section{THE PREPARATION AND USE OF SOMA/HAOMA}

Soma/haoma juice is pressed three times a day (morning, noon, and evening) in the Brahmanical tradition (see Kane, 1997, Vol. 2, Part 2, pp. 1174-1204) and twice (morning and evening) in the Zoroastrian tradition (Boyce, 2012). During soma rituals, participants sit around usually three (but in some instances five) prepared and sacred fireplaces that have been carefully orientated to the cardinal directions and excavated from ground in a high place. Reciting long and complex sequences of mantras from their sacred texts and offering substances such as ghi (clarified butter) into the fire, Brahman priests and other participants consume soma every 2 or $3 \mathrm{hr}$ during rituals that may last 1 day or many days. The mantras and hymns that are recited during rituals are contained in the samhita portions of the $V e d a$ s (composed between 1600 and 800 BCE), being the sacred texts of the Brahmans. Zoroastrians recite mantras/ manthras and hymns from the Avesta, the oldest parts of which date back to around 1600-1200 BCE.

In the Vedas and the Avesta, soma/haoma is described as a plant, the extract of a plant, and also as a deity. In the Vedas, Soma is the third most invoked deity, after Indra (the king of the Gods) and Agni (the God of fire). Soma is sometimes paired with other Vedic deities, notably Agni, Indra, Pūsan, or Rudra. Soma/haoma is praised in the highest terms. All of the 114 hymns of the ninth mandala (book/circle) of the 10 mandalas of the Rgveda, which is the oldest and most important of the Vedas, are dedicated to soma. Mantras and hymns dedicated to soma are also in the other three Vedas (Yajurveda, Sāmaveda, and Atharvaveda). Soma/haoma is prepared from stalks of plants, which in Zoroastrian practice are crushed in a mortar and pestle to extract the juice, and usually by pounding with stones on planks of wood in the tradition of the Brahmans of South Asia. Preparation of soma by mortar and pestle is also mentioned in the Vedas ( $R V$ 1.28.1-4).

In the Hōm Yašt, which is a section of the Avesta devoted to haoma (see Josephson, 1997; Pirart, 2003), it is said that the bundles of haoma stalks are collected by women ( $Y$ 10.17). In the Vedas and ancillary texts, it is described how bundles of soma stalks are purchased from a soma seller and then ceremonially taken to the arena of the sacred fires. In these texts, it is apparent that the juice from imperfectly pressed stalks, which have nodes and sections (parvan), is squeezed out by the presser's fingers (Bhawe, 1957, Part 1:7, pp. 71-72; Hillebrandt, 1980, Vol. 1, pp. 137-138). After the juice is extracted, it is mixed with water and a milk product (usually milk but also sometimes with yogurt) and sometimes also with honey and barley groats.

Before drinking soma/haoma, the consumer fasts (or observes dietary restrictions, such as abstaining from meat) and should remain celibate. Also prepared and offered to the Gods by the priests, and then eaten before drinking soma are small cakes/bread/pancakes (purodāśa), which have been fried, boiled, or baked, are made from either rice or barley. These breads are known as drōn bread in the Zoroastrian tradition. These breads settle the stomach, acting as a stay and preventing the purgative soma/haoma juice from flowing straight through the consumer (Gonda, 1982, p. 46).
These days Brahman priests prepare soma from nonpsychoactive plants, mostly the vine-like plants Sarcotemma brevistigma or Periploca aphylla. However, they know that they are nowadays using substitute plants, which they have been doing for probably more than a thousand years, and that they are not preparing the "real" soma. In the Brāhmanas, which are texts that form a part of the Vedic corpus dating from $c .800 \mathrm{BCE}$, there are many references to substitutes for or alternatives to soma, should the "real" soma be unavailable (see Swamy, 1976). Most of these alternative plants are of uncertain botanical identity; several appear to be different kinds of grasses, which may be psychoactive (see below).

Around $800 \mathrm{CE}$, most Zoroastrians migrated from Persia to India, owing to Muslim persecution, eventually settling in Mumbai, where they are known as Parsis. In their rituals, haoma was prepared from stalks of the ephedra bush imported from Persia until several decades ago (Modi, 1922). It was discovered in the 19th century that ephedra is also used by Zoroastrians of Yazd in Iran (O'Flaherty, 1969, pp. 118, 122).

The Vedas and the Avesta inform us that soma/haoma juice has a sharp ( $t \bar{v} v r a)$, bitter taste. It is usually described as yellow, golden, reddish, brown, or tawny in color. The juice is made from a plant (or plants) with no flowers or leaves (it seems probable that the plants used may originally have had leaves, but when the bundles of soma are purchased the leaves have been removed, leaving only the stalks). Soma/ haoma is said to provide health, truth, wisdom, power, poetic inspiration, and immortality. It could "possess" the consumer, as would a spirit or entity; it could further the power of action and also inspire warriors in battle. There are also Vedic soma rites for sorcery, based on the Samaveda (Parpola, 2015, p. 134ff.). The effect of soma/haoma could be an ordeal. It was also a purgative; it caused vomiting [for references to vomiting soma (in the Brähmanas and other texts), see Clark (2017, p. 55)]. Importantly, one of the many names for soma in the Vedas is amrta, meaning "non-death" or immortality. This is the "nectar of immortality," famed in Hindu myth.

\section{THEORIES ABOUT THE BOTANICAL IDENTITY OF SOMA/HAOMA}

Around 250 years ago, scholars began speculating and theorizing about the possible botanical identity of soma/ haoma. Dozens of theories have been published. The two most comprehensive surveys of the botanical identity of soma/haoma are by O'Flaherty (1969) and Houben (2003). Candidates for soma/haoma include various kinds of alcohol, the San Pedro Cactus (Echinopsis/Trichocereus pachanoi) (proposed by Di Maio, 2013), the lotus or water-lily plant (Nymphaea caerulea; this plant was first proposed by C. Cohen in 1919, and more recently by Spess, 2000 and McDonald, 2004; see also Emboden, 1979. This proposition is discussed further by Clark, 2017, pp. 108-109), ginseng (by Windfuhr, 1985), datura (Datura metel; proposed by Jones, 1995), mandrake (Mangragora turcomanica; by Khlopin, 1980. See also Sinev, 2016 for the cultivation of 
the plant in Central Asia), an ergot fungus (Claviceps paspali; by Greene, 1992; Shelley, 1995), cannabis (the proposition that soma/haoma was cannabis was first published by Brown, 2010 [1890], p. 84). Mukherjee's (1921) article attracted far greater scholarly interest. More recently, the theory has been revisited by Swamy, 1976; Waradpande, 1995; and Bennett, 2010), and various non-psychoactive plants, particularly S. brevistigma and Periploca aphyla, as these latter plants are sometimes used in contemporary rituals as soma (scholars have also proposed that soma is merely a concept, i.e., is rainwater, or that it was the product or ingredient of secret alchemical processes). Some scholars, such as Pokras (1991), still argue that S. brevistigma is one of the plants that is soma. Even though this plant has some minor medicinal use as a tonic, it is nevertheless far too weak to be considered as a psychoactive candidate for soma.

Besides these propositions, the three candidates that currently enjoy the greatest degree of scholarly support are ephedra (in particular, the ephedrine-yielding species Ephedra gerardiana, Ephedra procera, Ephedra intermedia, or Ephedra equistina), fly-agaric mushrooms (Amanita muscaria), and Syrian/mountain rue (Peganum harmala); these are considered in more detail below.

Regarding the other propositions mentioned, the use of alcohol (surā), particularly by Brahmans, was generally frowned upon in ancient India (Rahurkar, 1974). Soma and haoma are sometimes contrasted as opposites in both the $V e d a$ and the Avesta, so the idea that soma was some kind of alcoholic preparation can confidently be ruled out.

Unless further evidence is forthcoming, it seems highly improbable that the San Pedro cactus was soma because botanists are unanimous that the pachanoi species is only to be found indigenously in the Americas, and Trichocereus pachanoi only in parts of South America (see RohasAréchigas \& Flores, 2016, pp. 21-25, for an overview of the global distribution of the cactus family Cactaceae).

The other candidates that have been proposed appear to be either too weak, particularly when used regularly or on the other hand too toxic. These considerations would make it improbable that soma/haoma was either the lotus plant or ginseng or any of the other dozens of identification with plants that are only mildly psychoactive, as they would be too weak on their own.

Datura (D. metel, a type of "thorn apple") is occasionally mentioned in the context of "black" sorcery in South Asia and Tibet in some Tantric Buddhist rites (Parker \& Lux, 2008, pp. 7-11; Siklós, 1993), but it could be argued that the Datura species is generally too toxic and incapacitating for consideration as an entheogen suitable for use in the religious rites of soma/haoma, even though some species of datura are used by various communities in Africa and North, Central and South America for rites of passage, prophecy, divination, and for particular medical conditions (Schultes, 1972, pp. 46-49; Schultes, 1977, p. 255; Schultes \& Hoffman, 1980, pp. 270-272; Shepard, 2005, 3.4.2; Shepard, 2014, p. 23). Datura (synonymous with brugmansia and toé) is also sometimes added to ayahuasca concoctions in South America (Ott, 2006, p. 28).

Similarly, although mandrake has a history of use in medicine and magic (see Schenk, 1956, pp. 25-28; Schultes
\& Hofmann, 1980, pp. 296-299; Hatsis, 2015, pp. 76-88ff.), its generally sedative and toxic properties would seem to make it an improbable soma/haoma candidate. Even though the ergot fungus has various medical applications, untreated it is also highly toxic (see Bové, 1970 for a comprehensive history and analysis of ergot).

Even though cannabis, another of the botanical candidates, can have a strong and occasionally psychedelic effect, only rarely does it have the effect on regular consumers similar to that of a stronger psychedelic drug, such as LSD, psilocybin, or ayahuasca. There is a possibility that soma/ haoma was a plant that has become extinct, perhaps due to climate change or overharvesting. However, if soma/haoma was a single psychedelic plant of some kind, it would seem highly improbable that we have not yet found it.

\section{SOMA/HAOMA: THE STIMULANT EPHEDRA OR A PSYCHEDELIC?}

Looking at the sacred texts, it is apparent (and all scholars agree on this point) that soma kept consumers awake: it stimulated the ritualist. As noted previously, ephedra has been used by Zoroastrians as haoma. Furthermore, in many local languages in South and Central Asia, ephedra is called som/hum/hom and the like. Ephedra sinica has a long history of use in Chinese medicine, where it is known as ma huang. The leading scholarly consensus on the botanical identity of soma/haoma is that it was (and still is) ephedra (Staal, 2008, p. 100). Boyce (2012), Falk (1989, 2002 2003), Madhihassan (1987), Nyberg (1997), Qazilbash (1960) have presented cogent arguments in favor of ephedra.

However, other scholars (see, e.g., Thompson, 2003) have argued that soma appears to have been capable of producing visionary or psychedelic effects, as attested to in a few passages in the Vedas and ancillary texts and in the Avesta. However, this is disputed by supporters of the ephedra thesis. Nevertheless, in the Vedas and Avesta, there is occasional mention by the poets themselves of how soma can transport one into the sky, into light, into Truth, and the realm of immortality (see, e.g., Rgveda 8.48.3-4; 9.64.4, 8; 9.107.20; 9.113.9; Hōm Yašt, 9-11). In both the Vedas and the Avesta, the term soma/haoma is frequently used in association with the term mada/madha (or one of its variants), meaning strong, inspirational "intoxication," or brilliant, bright, or lifeinvigorating, which is not of the kind produced by drinking alcohol.

The argument presented in this article is really an attempt at answering, firstly, basic questions: if soma/haoma was a drug (which is now almost universally accepted by commentators), what kind of drug would be suitable for consumption during the recitation of a (sometimes lengthy) Vedic ritual; that could be drunk every few hours without impeding the ability of highly intoxicated ritualists to recite mantras precisely; that would keep participants awake; that produces no side-effects or hang-over (participants feel "reborn" after a ritual and do not seem to be "recovering" from a drug experience, as they might from consuming a stimulant such as ephedra every few hours for several days); and that could be consumed regularly throughout a 
consumer's life, and for many generations of participating ritualists, without any deleterious effects? These requirements seem to me incontrovertible concerning any candidate for soma/haoma. Secondly, as is suggested in this article, if soma/haoma is indeed visionary or psychedelic, then we need to find a psychedelic drug that fits these primary criteria. These considerations are what initially led me to the ayahuasca analogue hypothesis, as the structure and performance of the ritual during which ayahuasca is drunk by members of one the churches that use it as a sacrament, namely the church of Santo Daime, exhibit similarities with the ritual structure of the longer, periodic Vedic rites, during which soma is consumed (although for many centuries prepared in substitute form). This illustrates the possibility that an ayahuasca analogue could have been consumed in Vedic or Zoroastrian rituals over many years without deleterious effects or impeding the performance of a ritual.

It is suggested that Vedic and Zoroastrian rituals originally evolved primarily as vehicles for an entheogenic experience. Dietary preparations, spending the night prior to a ceremony in hut in the ritual arena, the generally sacred environment, the formal opening and closure of rituals, the singing and chanting of set sequences of mantras, and the prescribed ritual space overseen by trained and experienced priests would provide a secure, defined and appropriate "hologram" within which an entheogenic trip could have been most safely undertaken: a transition into a near-death realm.

\section{FLY-AGARIC MUSHROOMS (AMANITA MUSCARIA)}

Therefore, if soma was indeed originally some kind of psychedelic or visionary concoction, what could it have been? In 1968, the American banker-turned scholar, R. Gordon Wasson, the great pioneer of ethnomycology, published Soma: The Divine Mushroom of Immortality. In this very influential book and in several subsequent articles, Wasson argued that soma was the red and white-spotted flyagaric mushroom (A. muscaria). This mushroom is still consumed in parts of Afghanistan (Falk, 2002-2003, p. 145) and in western and northeastern Siberia (Wasson, 1969). A. muscaria is also used by some North American-Indian communities, in particular by the Ojibway in a shamanic context, in the border region of Canada and the USA (Navet, 1988). Some scholars still base their discussion of the flyagaric candidate on the erroneous presumption that this mushroom does not grow in India. However, it has been found growing in Jammu and Kashmir, around Manali and on the Rothang Pass (Himachal Pradesh), in Kodaikanal (Tamil Nadu), and in Guntur (Andhra Pradesh), although perhaps introduced into Guntur by Europeans (Rawala, Rawala, \& Sharma, 2002, p. 34). To date, the fly-agaric thesis is the only properly psychedelic candidate - besides datura, which is more accurately described as a hallucinogen that has been proposed by scholars as soma/haoma. However, opponents of Wasson's proposition have pointed out several possible objections to this thesis.

Even though each of the objections mentioned below has possible counter-arguments, which have all been articulated by commentators in the past 50 years or so, it seems that cumulatively the objections that have been raised by scholars in this field amount to considerable evidence against Wasson's thesis. Firstly, fly-agaric mushrooms do not need vigorously crushing with stones or in a mortar and pestle, as is performed in both Vedic and Zoroastrian traditions; the caps are natively consumed either whole, dried, or peeled

Secondly, it is clear from references in the Vedas and Avesta, as previously mentioned, that soma/haoma is purchased in the form of bundles of stalks with nodes or knots (parvan), which does not really fit with stipes of mushrooms.

Thirdly, Wasson (1971, pp. 177-178) also proposes a "third filter," whereby the urine of someone who had previously eaten the mushrooms is drunk. The first filter, according to Wasson, was sunlight; the second was the sheep-wool filter used to purify the soma juice; the third was the human body (purifying the urine). This happens in Siberia, as the toxins in the mushrooms can be partially eliminated in the urine of the consumer (Feeney, 2010). However, Wasson's evidence of this practice supposedly alluded to in the Vedas relies on incorrect translations of various passages presented to support this idea (Brough, 1971, 1973; Ingalls, 1971). In particular, Wasson incorrectly interprets $R V$ 9.74.4 as evidence of this practice. However, this passage states that, "the swollen men/heroes (=the Maruts) piss down (the fluid) set in motion" (trans. Skjærvø, 2004, p. 266). Other passages in the Rgveda (e.g., 1.64.5-6; 8.4.9-10) also refer to Indra or his companions (the Maruts and their horses) pissing after drinking soma and releasing thundering streams of fertilizing rain.

Wasson's (1971, pp. 171-178) notion of the "third filter" for the soma juice derives from two passages in the Rgveda (9.73.8; 9.97.55). However, $R V 9.73 .8$ merely refers to soma being thrice purified, while $R V$ 9.97.55 states that, "The three purifiers are spread out" (trans. Kashyap) (sam tri pavitrā vittāni eși). However, there is no evidence in any of these passages that the pissed soma is drunk, as in Siberia.

Fourthly and crucially, there are prohibitions (abhaksya) on the consumption by Brahmans of any kind of mushroom, which date back to the earliest Brahmanical law codes (dharmaśāstra), framed in the early centuries BCE. Falk (2002-2003, p. 147) comments that, "Not a single reference leaves room to doubt this" (see, e.g., Manusmrti, 5.5, 19; 6.14; 11.156; see also Padhy \& Dash, 1997; Falk, 2002 2003, p. 146, for further references).

Fifthly, another argument against the fly-agaric thesis is perhaps provided by recent psychedelic history. Certainly, since the publication of Wasson's book in 1968, the psychedelic properties of these mushrooms have been well known. These mushrooms commonly grow in Europe, Asia, Mesoamerica, North America, and Russia, and nearly everyone knows about them, even those not interested in psychedelics. However, the general enthusiasm and often reverence by psychonauts for the "classic" tryptamines - for LSD in the 1960s and 1970s, for psilocybin mushrooms (beginning in the mid-1970s), and for ayahuasca since the early 1990s - has never been even remotely matched by flyagaric. Who regularly eats or drinks fly-agaric? Pendell (2010, p. 204) comments "For the Queen of Entheogens, it's all pretty muted. One would expect more. (I mean, compare it to say, mandrake.) From a distance, the silence 
in the hall is louder than the one or two who are clapping. The only people shouting are the Siberians."

The general lack of enthusiasm for fly-agaric is no doubt because of the effects, which provides the sixth possible objection to the proposition. Intoxication with fly-agaric mushrooms is quite destabilizing: although capable of producing significant psychedelic effects, the mushrooms also usually cause dizziness, stomach cramps, tremors, and blurred vision. McKenna (1992, p. 109) reports twice consuming fly-agaric; he felt nauseous and experienced stomach cramps and blurred vision. Beyer (2010, p. 287) remarks that although small doses of Amanita can produce euphoria, "doses large enough to cause hallucinations which appear to occur only rarely and sporadically - are physically incapacitating, with effects including drowsiness, confusion, muscle-twitches, loss of muscular coordination, and stupor." Wasson himself tried fly-agaric mushrooms several times but never had an ecstatic experience; he only felt tired and nauseous (Wasson, 1969, p. 75).

Wasson's initial interest in the possible role of fly-agaric mushrooms as soma was prompted by a conversation with Wendy Doniger (O'Flaherty), the Sanskritist who worked with him on his Soma book, and who contributed a large section on the history of botanical identifications, but she was always skeptical of the hypothesis (Doniger, 1997). Nevertheless, it seems that Wasson remained convinced of the fly-agaric theory until the end of his life (Ott, 1998, p. 17); although, curiously, he seems to have become aware in Persephone's Quest, published in 1986, that there might be problems with his thesis (Wasson, Kramrisch, Ott, \& Ruck, 1986). He wonders (pp. 89, 135) about the role of Stropharia cubensis (psilocybin mushrooms) in India; he also remarks (p. 89): “We may recall [though readers were not informed previously about this important point] that in India Hindus of the upper classes are forbidden by their religion to eat mushrooms of any kind."

However, although there are negative accounts of intoxication by fly-agaric, there is evidence of positive experiences with the mushrooms. Besides clairvoyance, inducing communication with souls of the dead and other spirits, facilitating knowledge of lost items, and visiting "other worlds," there are also reports of being capable of walking, running, and hunting all day without fatigue, undertaking strenuous manual labor, and being able to sing otherwise forgotten folk epics vigorously all night. Siberian reindeer hunters who chewed the mushrooms became more nimble; a Chukchi mam claimed he could walk for hours in the snow without snowshoes; another man reported increased strength to harvest hay (Furst, 1988, pp. 38, 51-59; Saar, 1991).

Heinrich (1995, pp. 191-198) reports eating the mushrooms every day for a month in 1977. After initial experiences of nausea and discomfort, he (and his friend) finally obtained a magnificent, revelatory experience. Heinrich was absorbed into the unsurpassable light of the Godhead. Attempting to repeat the experience, he eagerly ate the mushrooms a few days later, only to be plunged into hell. Such entheogenic experiences from fly-agaric are, nevertheless, quite rare.

Some supporters of the fly-agaric thesis point out that there are ways of improving the effect of the mushrooms. It has been demonstrated that consuming fly-agaric mushrooms that have first been dried substantially reduces toxicity (Feeney, 2010), as does drinking the urine of a prior consumer. However, as it seems that Wasson was wrong about Vedic priests drinking urine (as mentioned above), this aspect of the proposition does not need consideration in the context of South Asia. However, drying the mushrooms, although reducing toxicity, would still not, in this author's view, sufficiently reduce toxicity for the kind of experience desired, although this is of course debatable.

Despite the objections mentioned above, a few scholars (e.g., Levitt, 2011; Stuhrman, 1985) nevertheless maintain that fly-agaric mushrooms were the "original" soma. Smith (1972), who supports Wasson's theory, provides a summary of 14 assessments, both positive and negative, of Wasson's fly-agaric thesis. Not all Sanskritists disagree with it. However, several other scholars (e.g., Staal, 2008, p. 100), although believing Wasson to be wrong about fly-agaric being soma, nevertheless, credit him with being the first person to bring to attention the probability that soma was a psychedelic of some kind.

\section{SYRIAN/MOUNTAIN RUE (PEGANUM HARMALA)}

In 1989, David Flattery and Martin Schwarz proposed, alternatively, in their learned publication Haoma and Harmaline, that soma/haoma was Syrian/mountain rue (P. harmala). This plant, which is widely dispersed, has a long history of medicinal use in Central Asia and elsewhere; it is also used as a red dye and as an aphrodisiac. Consumption of the angular reddish/brownish seeds produces a dreamy and generally introverted condition. In a pioneering study conducted in 1964 of the effects of harmine and harmaline, which are monoamine oxidase inhibitors (MAOIs) and the active ingredients in the seeds of rue, the researcher Naranjo (1973) described the effects as oneirophrenic (dream-inducing) and conducive to psychoanalytic investigation. However, Syrian rue is not a visionary or psychedelic plant. At doses sufficient to produce psychedelic effects, the experience usually becomes unpleasant and destabilizing (Jay, 1999, p. 68ff.).

In summary, at present, there are three theories about the botanical identity of soma/haoma that still have some scholarly support, namely ephedra, fly-agaric mushrooms, and Syrian rue. It has been suggested that none of these three candidates seem to meet all the necessary requirements to be identified as soma/haoma.

\section{THE AYAHUASCA ANALOGUE HYPOTHESIS}

Across the Amazon region of South America, there is a persistence of ayahuasca use in mestizo communities. Their ayahuscaca is usually prepared from at least two plants, namely Banisteriopsis caapi, a vine that contains the $\beta$-carboline derivatives harmine, harmaline, and tetrahydroharmine, which act as MAOIs, and Psychotria viridis, a plant that contains $N-N$ dimethyl tryptamine (DMT), a potent psychedelic. Orally consumed DMT is rapidly broken down by enzymes in the human gut, and ineffective unless combined with an MAOI, which inhibits the 
breakdown by enzymes. Other plants are used in various combinations as additives to the formula, as boosters, or enhancers. The effects of ayahuasca include visions, healing, clairvoyance, inspiration, seeing light and geometric patterns, sensations of flying and immortality, and of an encounter with the force of life. Ayahuasca is a purgative and it can be a terrifying ordeal. It is also occasionally used in the context of war by some South American tribes (De Mori, 2011, p. 28; Saés, 2011, p. 136).

The hypothesis presented in this article (and in greater detail in The Tawny One: Soma, Haoma and Ayahuasca) is that, by the late Bronze Age (c. $1600 \mathrm{BCE}$ ) in Central Asia (in the upper-Oxus region, in what is now Turkmenistan), there was sufficient botanical knowledge to manufacture analogues of ayahuasca from various plants, by combining at least one plant containing DMT and another containing an MAOI. Ott (2006, pp. 25-28) categorizes 100 different additives to native ayahuasca concoctions; it could have been similar in ancient Asia. Similarly, Luna (1984, p. 141) lists 33 plants that are sometimes added in Peru to the $B$. caapi plus $P$. viridis ayahuasca combination. Ott (2006, pp. 18-19) also discusses stimulants such as guaraná and coca that are added by some groups to their ayahuasca formulas. It could have been similar in Asia where ephedra stalks or other plants containing ephedrine could have been added to the formula. Similarly, it seems feasible that other psychoactive plants such as cannabis could have been additives, as enhancers. The formulas for soma/haoma most probably varied, depending on geographical location and the availability of plants. Essentially, what is being suggested is that soma/haoma simply meant a formula of plants sufficiently and reliably potent to induce a "properly" entheogenic experience.

It is now known that around 70 plants contain DMT (in various amounts) and that around another 60 plants contain MAOIs, in one form or another (Ott, 1996); these plants are globally distributed. Ott (1997, 2011, p. 109ff.) maintains that the effects of the $4,200(60 \times 70)$ various possible combinations of these plants are very similar. More plants containing these chemicals are being discovered almost every year (Ott, 2001).

In both the Avesta and the Vedas, there are references to many kinds of soma/haoma, which have baffled some scholars under the impression that soma or haoma refers to just one plant. There are references in the Rgveda to what seem to be several kinds of plants and trees called soma growing in a variety of habitats ( $R V$ 9.65.23; 10.94.3.3; $10.89 .5 .4 ; 10.97 .7)$. In the Avesta ( $Y 10.12,17)$, haoma is said to have been "of many kinds" (Boyce, 1975, p. 158). The word haoma frequently occurs in the Avesta in the plural. Boyce (2001, p. 5) remarks that, "The ritual offering to the waters at the end of the yasna [ritual worship] was prepared from milk, the leaves of one plant and the juice obtained from pounding the stems of another."

This plurality of plants is also reflected in the Indian materia medica, where around 20 plants are called soma (Nadkarni, 1954; Srivastava, 1966). All of these plants, this author suggests, might have been used at one time or another in the manufacture of soma, either as "main" or additional plants.

There are several plants mentioned in the Vedas and ancillary texts that seem to be contenders as either main or subsidiary plants used in the soma formula at one time or another. Among the plants that I suggest may have been used as part of the formula are: Syrian/mountain rue ( $P$. harmala), which is known in Bengal and other regions of India as som (William Jones first proposed this plant as soma in 1794); kuśa/dharba grass (Desmostachya bipinnata), which is closely associated with soma; the kustha plant, which is also associated with soma; and giant reed (Arundo donax).

Kuśa/darbha grass is ubiquitous in both Brahmanical and Buddhist rituals (see Clark, 2017, pp. 151-154, for further details); it is a relative of Phalaris grass, some samples of which have quite a high DMT content, although this varies enormously. Some samples of the 20 or so varieties of this plant that have been tested had no DMT, while others had a high content. The variability is due to numerous factors, including locality, humidity, available light, soil type, season, and the time of day of the sample harvest (see Festi \& Samorini, 1993, 2004 for an analysis of various samples). Kuśa/darbha grass, the species that grows in South Asia, has never been properly tested for alkaloid content, except for one (negative) test kindly conducted on dry grass on behalf of the author, by Professor Simon Gibbons at the London School of Pharmacy.

As noted previously, in the Brāhmanas and Śrautasūtras, a dozen or so plants, most of uncertain botanical identification, are mentioned as "substitutes" or alternatives to soma, should the "real" soma be unavailable (Kane, 1997, Vol. 2, Part 2, p. 1203; Swamy, 1976). Most of these plants seem to be grasses of one kind or another. It seems possible that these grasses may, like Phalaris, be potentially psychoactive.

In the Arharvaveda (5.4), the kustha plant is revered in the highest terms; it is also mentioned in connection with soma (19.39.5-6, 8). One of the botanical identifications of kustha is as wild ginger (Costus speciosus). However, could it instead be fragrant ginger/galangal (Kaempheria galangal)? Galangal is a common ingredient in Asian cooking, grows in India, and also has strong MAOI properties (Noro, Miyase, Kuroyanagi, Ueno, \& Fukushima, 1983; Toro \& Thomas, 2007, p. 46).

Tryptamines, including DMT, bufotenin, and traces of 5-MeO-DMT, have been found in samples of $A$. donax (Al-Snafi, 2015, p. 35; Trout, 2002, p. 27). The results of bioassays of a variety of specimens from the USA were mixed (DeKorne, Aadvark, \& Trout, 2002, pp. 126-131); some samples were found to contain no DMT; others had alkaloids that caused nausea; others tested positive for DMT. Native samples tested in India have the highest DMT content that has been found (Trout, 2004a). In the Avesta, a plant called hadhānaēpata is praised alongside haoma (see $Y$ 3.3, Y 22.1, Y 52.9, Y 66.1, Y 68.1; see also Visperad 11.2). It is sometimes translated as "pomegranate" - a fruit divinized in the Mediterranean region and the Middle-East since the time of the Sumerian empire (c. 3000 BCE; Nigro \& Spagnoli, 2018) - which is currently used in Zoroastrian rites. Taillieu (2012) comments that, "In the known Zoroastrian rite a pomegranate twig is used, but this must be a substitute for the original plant." The Avestan term hasāna means "with many seeds." Other references in the Avesta indicate that it is a soft wood that smells sweet when burnt (Flattery \& 
Schwarz, 1989, p. 76ff.). The author suggests that this plant may possibly be $A$. donax.

Several trees also feature throughout the Vedic commentarial tradition either as soma, as "substitutes" for soma or in association with soma. Most mentioned in this regard are Butea frondosa/monosperma (flame of the forest/ palāśa), Ficus infectoria (wavy-leaf/white fig/plakșa), Ficus glomerata/racemosa (Indian or cluster fig/udumbara), Ficus religiosa (peepal/bodhi/aśvattha), and Ficus bengalensis/benghalensis (banyan/nyagrodha/vața). The plakșa, udumbara, peepal, and banyan trees are regarded as particularly sacred in the Hindu tradition, being four of the five "holy" trees, the fifth being the mango tree; the peepal is the most holy (Pandey, 1989, p. 22). None of these plants has ever been properly tested for alkaloids or psychoactive properties. My hunch is that all these trees may have psychoactive properties. Four of these five trees are included in formulas for amrta/soma (see below); although until comprehensive tests have been undertaken, the supposition regarding these trees remains speculative.

India's earliest preserved medical text, the so-called Bower Manuscript, a text from Kashmir dating to the 6th century CE, has two formulas for amrta (soma) for use in a therapeutic - in distinction from an entheogenic - context (Hoernle, 2011, pp. 20n.64, 90, 106). These two formulas include dozens of different plants, many of them of uncertain botanical classification. Included in the two formulas are most of the plants mentioned above, including kuśa, plaksa, udumbara, aśvattha (peepal), and nyagrodha (banyan). Leonti and Casu (2014) analyze these formulas for amrta in the Bower Manuscript and observe that, although the exhilarating effects of these concoctions are not described, the presence of both DMT and MAOIs in several of the constituent plants would, nevertheless, produce exhilarating effects. They propose that this formula, probably in a stronger form (or dose), was the basis of the soma of the Vedas.

Having detailed the dozens of plant ingredients for these two formulas, Leonti and Casu provide the botanical details and chemistry of six kinds of plants, which occur in both formulas for amrta. Also included in both formulas, but not specifically discussed by Leonti and Casu, is kṣiravidārī/ vidārī (Ipomoea digita), possibly (but uncertainly) a source of lysergic amide acid (LSA or ergine), which can induce psychedelic effects.

All six plants discussed by Leonti and Casu are native to South Asia and are known to have psychoactive properties: (a) Desmodium gangeticum (Fabacae); (b) Mucuna pruriens (Fabaceae); (c) Nelumbo nucifera (Nelumbonaceae); (d) Sida rhombifolia, Sida spinosa, and Sida cordifolia (Menispermaceae); (e) Tabernaemontana divaricata (Apoynaeae); and (f) Tinospora cordifolia (Menispermacea). Leonti and Casu comment (p. 382) that for many of the other species of plants mentioned in the recipes, no or only scarce phytochemical and pharmacological data exist.

D. gangeticum (Sanskrit: śālaparni/soma) is rich in both DMT and 5-MeO-DMT (Shulgin \& Shulgin, 1997, p. 208; Trout, 2004b, p. 9).

M. pruriens (Sanskrit: kappicacchu/ātaguptā), Bengal velvet bean/cowhage, similarly contains both DMT and, in trace amounts, 5-MeO-DMT (Ghosal, Singh, \& Bhattacharya,
1971; Trout, 2002, p. 122). This plant also contains L-3-4dihydroxyphenylalanine, which is used to treat Parkinson's disease.

$N$. nucifera (lotus plant) contains no tryptamines but is mildly psychoactive, owing to nuciferine and nornuciferine, which, apart from medicinal uses, particularly in China, act as mild, opiate-like sedatives.

All three of the Sida species discussed by Leonti and Casu (S. rhombifolia/arrowleaf sida, S. spinosa/prickly fanpetals, and $S$. cordifolia/flannel weed/country mallow) contain the stimulant ephedrine, besides other alkaloids, including carboxylated tryptamines (Pramanick, Maiti, \& Srivastava, 2015, p. 130).

The fifth plant considered, T. divaricata (pinwheel flower/ crape jasmine/East India rosebay; Sanskrit: nandīvrkṣa) contains at least 42 different alkaloids, including a substantial amount of ibogaine (Leonto \& Casu, 2014) (For the use of iboga in a native context in Gabon, see Fernandez, 1982, p. 470ff.; Schultes, Hofmann, \& Rätsch, 2001, pp. 112-115. For the chemistry and botany of ibogaine, see Schultes \& Hofmann, 1980, pp. 235-239).

The sixth plant, T. cordifolia (heart-leaved moonseed; Sanskrit: madhuparni/guducī/somavallī/amrta), contains jatrorrhizine, berberine, and plamatine, all of which, individually, have been demonstrated to be MAOIs (MAOI-A and MAOI-B; for further details, see Clark, 2017, pp. 141-146).

Leonti and Casu conclude that, taking into account both the qualitative and phytochemical profiles of the plants discussed, a psychoactive potion could most probably be obtained by making a concentrated MAOI juice of $T$. cordifolia with either D. gangeticum (which contains DMT) and/or a Sida sp. extract, which in high doses could induce a psychedelic experience. They comment that the alkaloid content of particularly $T$. cordifolia and $D$. gangeticum is considerable. The combination of T. cordifolia with a species of Sida would produce more of a stimulant, amphetamine-like effect, owing to the presence of ephedrine, whereas a combination of $T$. cordifolia with $D$. gangeticum, with less of a Sida species, would also be psychedelic, but less stimulant. The combination of these plants with others containing alkaloids including ibogaine (in T. divaricata) and nuciferine (in N. nucifera) would also result in a psychoactive potion.

Suffice it to say that these plant in various possible combinations and in appropriate doses could work entirely adequately as ayahuasca analogues. This is without taking into account the possible effects of the other plants listed in the formulas, for which, as mentioned previously, very little (if any) information is currently available on their potentially psychoactive properties.

That said, there are, nevertheless, several rejoinders that could be mounted to the proposition advanced (other issues are addressed by Clark, 2017, pp. 205-209). One of the pertinent puzzles is that if psychoactive plants capable of producing an entheogenic experience were known about 3,000 years ago, why has that knowledge disappeared, as there appears to be no trace of a contemporary, active, entheogenic cult in India? To this, the author has no answer. It also needs to be emphasized that there is so little relevant information available in either texts or inscriptions that all hypotheses regarding soma/haoma remain tentative. 
Although, in this article, doubt is cast on the theories of (solo) ephedra or mushrooms, these doubts are possibly unfounded. However, having looked at all the available evidence, taken into account nearly everything that has been published on this topic, and considered the range of effects that can be engendered by all of the potentially entheogenic plants currently known, it seems that the ayahuasca analogue hypothesis comes closest to answering all the objections that have been raised by scholars concerning other theories about the botanical identity of soma/haoma.

However, another question remains concerning the feasibility of extracting sufficiently psychoactive juice from plants through cold pressing with either stones or mortar and pestle, as in the Vedic tradition soma is always an uncooked oblation. A few anecdotal reports of trips on cold-pressed extractions of various plants used as ayahuasca analogues have been published (see various reports in Clark, 2017), but this needs further research as most of the plant combinations mentioned in this article have never been properly, quantitatively analyzed.

Acknowledgements: The research of this article was funded by the author. No financial contributions for this research were made to the author by SOAS or any other institution.

Conflict of interest: The author declares no conflict of interest.

\section{REFERENCES}

\section{Primary Sources}

Avesta:

Bleeck, A. H. (Trans.). (2005) [1864]. The religious books of the parsees (from Professor Spiegel's German Translation of the Original Manuscripts, in three volumes). Hertford: Elibron/ Muncherjee Hormusjee Cama.

Darmesteter, J. (Trans.). (1960) [1892]. Le Zend-Avesta (Vol. 1); La Liturgie (Yasna et Vispéred) (Vol. 2); La Loi (Vendidad), L'Épopée (Yashts), Le Livre de Prière (Khorda Avesta). Paris: Adrien Maisonneuve.

Mills, L. H. (Trans.). (1887). The Zend-Avesta, Part III: The Yasna, Visparad, Afrîgân, Gâhs, and Miscellaneous Fragments (Sacred Book of the East, Vol. XXXI, F. Max Müller, Series Ed.). Oxford: Clarenden Press.

\section{Hōm Yašt:}

Josephson, J. (1997). The Pahlavi translation technique as illustrated by Hom Yašt (Studia Iranica Upsaliensis 2). Uppsala, Sweden: Uppsala Universitetsbibliotek.

Pirart, É. (2003). L'éloge mazdéen de l'ivresse: Édition, traduction et commentaire du Hōm Stōd (Collection KUBABA, Série Antiquité IV). Paris, France/Budapest, Hungary/Torino, Italy: L'Harmattan.

\section{Manusmrti:}

Olivelle, P. (Ed. \& Trans.). (2004). The law codes of Manu. Oxford, UK/New York, NY: Oxford University Press.
Vedas:

Kashyap, R. L. (Ed. \& Trans.). (2007-2009). [Rgveda] Rig Veda Samhitā (Vols. 1-12). Bangalore, India: Sri Aurobindo Kapāli Sāstri Institute of Vedic Culture (SAKSHI).

Kashyap, R. L. (Ed. \& Trans.). (2008-2011). [Sāmaveda] Sāma Veda (Vols. 1-2). Bangalore, India: Sri Aurobindo Kapāli Sāstri Institute of Vedic Culture (SAKSHI).

Kashyap, R. L. (Ed. \& Trans.). (2008-2011). [Yajurveda] Yajur Veda (Taittirīya Samhitā) (Vols. 1-4). Bangalore, India: Sri Aurobindo Kapāli Sāstri Institute of Vedic Culture (SAKSHI).

Kashyap, R. L. (Ed. \& Trans.). (2011-2012). [Atharvaveda] Atharva Veda (Vols. 1-6). Bangalore, India: Sri Aurobindo Kapāli Sāstri Institute of Vedic Culture (SAKSHI).

\section{Brāhmanas:}

Dumont, P.-É. (1951). The special kinds of Agnicayana (or special methods of building the Fire-Altar) according to the Kathas in the Taittirìya-Brāhmana: The tenth, eleventh, and twelfth Prapāthakas of the third Kānda of the Taittirīya-Brāhmana with translation. Proceedings of the American Philosophical Society, 95(6), 628-675. Retrieved from http://www.jstor.org/ stable $/ 3143510$

Eggeling, J. (Ed. \& Trans.). (1995) [1882-1900]. ŚatapathaBrāhmana, according to the Mãdhyandana school (Parts $I-I V$ ). (Sacred books of the east, F. Max Müller, Series Ed., Vols. 12, 26, 41, 43, 44). Delhi, India/Oxford, UK: Motilal Banarsidass/Clarenden Press.

Houben, J. E. M. (Ed. \& Trans.). (1991). The Pravargya Brāhmana of the Taittiriya Āranyaka: An ancient commentary on the Pravargya Ritual. Delhi, India: Motilal Banarsidass.

Keith, A. B. (Trans.) (1925). The Aitareya and Kaușitaki Brāhmanas of the Rigveda (Harvard oriental series, Vol. 25). Cambridge, MA: Harvard University Press.

Mitra, R., \& Vidyābushana, H. (Eds.). (2012) [1872]. The Gopatha Brāhmana of the Atharva Veda (Bibliotheca Indica, new series, Vols. 215, 252). Calcutta: Asiatic Society of Bengal.

\section{Secondary Sources}

Abaev, V. I. (1975). Contribution à l'histoire des mots: 1. Vieiliranien hauma - et le nom eurasien du houblon. In J. Veyrenc (Trans.), Mélanges linguistiques offerts à Émile Benveniste (pp. 1-3). Paris, France: Société de Linguistique de Paris.

Al-Snafi, A. E. (2015). The constituents and biological effects of Arundo donax - A review. International Journal of Phytopharmacy Research, 6(1), 34-40. Retrieved from https://www.academia. edu/11580960/THE_CONSTITUENTS_AND_BIOLOGICAL_ EFFECTS_OF_ARUNDO_DONAX_-_A_REVIEW

Bartholomae, C. (1904). Altiranisches Wörtebuch. Strassburg, France: Verlag von Karl J. Trübner.

Bedrosian, R. (2000). Soma among the Armenians. Retrieved from http://rbedrosian.com/soma.htm. Accessed on: February 28, 2015.

Bennett, C. (2010). Cannabis and the soma solution. Walterville, OR: TrineDay.

Beyer, S. V. (2010) [2009]. Singing to the plants: A guide to mestizo shamanism in the Upper Amazon. Albuquerque, New Mexico: University of New Mexico Press. 
Bhawe, S. S. (1957, 1960, 1962). The Soma-hymns of the Rgveda: A fresh interpretation (Part 1: RV 9.1-15; Part 2: RV 9.16-50; Part 3: RV 9.51-70). Baroda, India: Oriental Institute.

Bové, F. J. (1970). The story of Ergot. New York, NY/Basel, Switzerland: S. Karger.

Bowman, R. A. (1970). Aramaic ritual texts from Persepolis (The University of Chicago Oriental Research Publications, Vol. XCI). Chicago, IL: The University of Chicago Press.

Boyce, M. (1975-1982). A history of Zoroastrianism (Vols. 1-2). Leiden, The Netherlands/Köln, Germany: E. J. Brill.

Boyce, M. (2001) [1979]. Zoroastrians: Their religious beliefs and practices. London, UK/New York, NY: Routledge.

Boyce, M. (2012) [1998]. Haoma ii. The rituals (Encyclopædia Iranica, Vol. XI, pp. 662-667). Retrieved from http://www. iranicaonline.org/articles/haoma-ii. Accessed on: February 27, 2015.

Brough, J. (1971). Soma and Amanita muscaria. Bulletin of the School of Oriental and African Studies, XXXIV(Part II), 331-362. Retrieved from https://archiveshub.jisc.ac.uk/search/ archives/adefa818-884c-3b44-ba63-1c65aa92930a?component= 708dfe2c-b7e9-3fc9-b0f1-a72d9c9e1de5

Brough, J. (1973). Problems of the "Soma-Mushroom" theory. Indologica Taurinensia, 1(Part 1), 21-32.

Brown, G. W. (2010) [1890]. Researches in oriental history (Kessinger Publishing's Rare Mystical Reprints 2nd ed.). Rockford, IL: Author.

Clark, M. (2017). The Tawny One: Soma, haoma and ayahuasca. London, UK/New York, NY: Muswell Hill Press.

Dandekar, R. N. (1958-1962). Śrautakośa (Based on the Śrautasūtras [Part 1] and the Kalpasūtras [Part 2] belonging to the various Vedic Schools) (English Section, Vol. 1, Parts 1 $\&$ 2). Poona: Vaidika Samśodhana Mandala.

DeKorne, J., Aadvark, D., \& Trout, K. (Eds.). (2002) [2000]. Ayahuasca analogues and plant-based tryptamines: The best of the entheogen review 1992-1999 (2nd ed.). Sacramento, CA: The Entheogen Review.

De Mori, B. B. (2011). Tracing hallucinations: Contributing to a critical history of ayahusca usage in the Peruvian Amazon. In B. C. Labate \& H. Jungaberie (Eds.), The internationalization of ayahuasca (Intercultural Studies on Ritual, Play and Theatre, Vol. 16, pp. 23-47). Zürich, Switzerland/Berlin, Germany: LIT Verlag.

Di Maio, P. (2013). Ethnobotanical identification of Echinopsis pachanoi in Himachal Pradesh. A new candidate for the soma plant? Retrieved from https://www.academia.edu/5399240/ Ethnobotanical_study_identifies_native_cactus_in_Asia_new_ candidate_for_vedic_Soma_Plant. Accessed on: February 15, 2014.

Doniger, W. (1997) [1990]. 'Somatic' memories of R. Gordon Wasson. In T. J. Riedlinger (Ed.), The sacred mushroom seeker: Tributes to R. Gordon Wasson (pp. 55-59). Rochester, VT: Park Street Press.

Emboden, W. A. (1979). Sacred narcotic water lily of the Nile: Nymphaea caerulea Sav. Economic Botany, 33(1), 395-407.

Falk, H. (1989). Soma I and II. Bulletin of the School of Oriental and African Studies, LII(Part 1), 77-90. doi:10.1017/ S0041977X00023077

Falk, H. (2002-2003). Decent drugs for decent people. Orientalia Suecana, LI-LII, 141-155.

Feeney, K. (2010). Revisiting Wasson's Soma: Exploring the effects of preparation on the chemistry of Amanita muscaria.
Journal of Psychoactive Drugs, 42(4), 499-506. doi:10.1080/ 02791072.2010 .10400712

Fernandez, J. W. (1982). Bwiti: An ethnography of the religious imagination in Africa. Princeton, NJ: Princeton University Press.

Festi, F., \& Samorini, G. (1993). Alcaloidi indolici psicoattivi nei generi Phalaris e Arundo (Graminaceae): una rassegna. Annali dei Musei Civici di Roverto, 9, 239-287. Retrieved from https://www.samorini.it/doc1/sam/samorini-festi-alcaloidi-psicoattivi-nei-generi-phalaris-e-arundo.pdf

Festi, F., \& Samorini, G. (2004). “Ayahuasca-like” effects obtained with Italian plants. Paper presented at Actas Il Congresson Internacinal para el Estudio de los Estados Modificados de la Consciencia, Instituto de Prospectiva Antropológica, Barcelona, Spain, pp. 62-71.

Flattery, D. S., \& Schwartz, M. (1989). Haoma and harmaline: The botanical identity of the Indo-Iranian hallucinogen "Soma" and its legacy in religion, language and Middle Eastern Folklore (Near Eastern studies, Vol. 21). Berkeley, $\mathrm{CA} /$ Los Angeles, CA/London, UK: University of California Press.

Flood, G. (1996). An introduction to Hinduism. Cambridge, UK/ New York, NY/Melbourne, Australia: Cambridge University Press.

Friedrich, W. L. (2009). Santorini: Volcano, natural history, mythology (A. R. McBirney. Trans.). Aarhus, Denmark: Aarhus University Press.

Furst, P. T. (Ed.). (1988) [1986]. Mushrooms: Psychedelic fungi (The encyclopedia of psychoactive drugs). London: Burke Publishing Company Limited.

Gershevitch, I. (1974). An Iranianist's view of the soma controversy. In Ph. Gignoux \& A. Tafazzoli (Eds.), Mémorial de Jean Menasce (pp. 45-75). Louvain, Belgium: Imprimerie Orientaliste.

Ghosal, S., Singh, S., \& Bhattacharya, S. K. (1971). Alkaloids of Mucuna pruriens: Chemistry and pharmacology. Planta Medica, 19(3), 279-294.

Gonda, J. (1982). The Haviryajñāh Somāh: The interrelations of the Vedic Solemn Sacrifices: Śänikhāyana Śrautasūtra 14, 1-3, translation and notes (Verhandelingen der Mededelingen der Koninklijke Nederlandse Akademie van Wetenschapen, AFD. Letterkunde, Nieuwe Reeks, Deel 113). Amsterdam, The Netherlands/Oxford, UK/New York, NY: North Holland Publishing Company.

Greene, M. T. (1992). Natural knowledge in preclassical antiquity. Baltimore, MD/London, UK: The Johns Hopkins University Press.

Hatsis, T. (2015). The Witches' ointment: The secret history of psychedelic magic. Rochester, VT/Toronto, Canada: Park Street Press.

Heinrich, C. (1995). Strange fruit: Alchemy, religion and magical foods. A speculative history. London, UK: Bloomsbury Publishing.

Herodotus. (1968) [1954]. The histories (A. de Sélincourt, Trans. \& Intro.). Harmondsworth, Middlesex: Penguin Books.

Hillebrandt, A. (1980-1981) [1927-1929]. Vedic mythology (S. R. Sarma, Trans., Vols. 1-2). Delhi, India: Motilal Banarsidass.

Hoernle, A. F. R. (2011) [1912]. The Bower manuscript (facsimile leaves, nagari transcript, romanised transliteration and english translation with notes). New Delhi: Aditya Prakashan [Calcutta: Superintendent Government Printing]. 
Houben, J. E. M. (2003). The Soma-haoma problem: Introductory overview and observations on the discussions. Electronic Journal of Vedic Studies [EJVS], 9(1a).

Ingalls, D. H. H. (1971). Remarks on Mr. Wasson's Soma. Journal of the American Oriental Society, 91(2), 188-191. doi:https:// www.jstor.org/stable/i225259

Jay, M. (1999). Blue tide: The search for Soma. Brooklyn, NY: Automedia.

Jones, R. L. (1995). The soma plant and the possible connections to the genus Datura (Thornapple Tree). Pennsylvania, PA: Department of South Asian Studies, University of Pennsylvania.

Joseph, T. (2017). How genetics is settling the Aryan migration debate. The Hindu. Retrieved from https://www.thehindu.com/ sci-tech/science/how-genetics-is-settling-the-aryan-migrationdebate/article19090301.ece. Accessed on: July 10, 2018.

Kane, P. V. (1977-1997) [1930-1962]. History of Dharmaśāstra (Government Oriental Series, Class B, no. 6, Vols. 1-5, 3rd ed.). Poona: Bhandarkar Oriental Research Institute.

Khlopin, I. N. (1980). Mandragora turcomanica in der Geschichter der Orientalvölker. Orientalia Lovaniensia Periodica, 11, 223-231.

Leonti, M., \& Casu, L. (2014). Soma, food of the immortals according to the Bower Manuscript (Kashmir, 6th century AD). Journal of Ethnopharmacology, 155, 373-386. doi:10.1016/j.jep.2014.05.029

Levitt, S. H. (2011). New considerations regarding the identity of Vedic sóma as the mushroom fly agaric. Studia Orientalia, 111, 105-118. Retrieved from https://journal.histories/article/ view/9308

Luna, L. E. (1984). The concept of plants as teachers among four Mestizo Shamans of Iquitos, Northeastern Perú. The Journal of Ethnopharmacology, 11(2), 135-156. doi:10.1016/03788741(84)90036-9

Macdonell, A. A. (1995) [1898]. Vedic mythology. Delhi, New Delhi: Motilal Banarsidass.

Madhihassan, S. (1987). The history and natural history of Ephedra as Soma. Islamabad, Pakistan: Pakistan Science Foundation.

Mahadevan, T. P., \& Staal, F. (2003). The turning-point in a living tradition: Somayāgam 2003. Electronic Journal of Vedic Studies [EJVS], 10(1a), 1-25. doi:10.11588/ejvs. 2003.1.743

Malandra, W. W. (Ed. \& Trans.). (1983). An introduction to ancient Iranian religion: Readings from the Avesta and Achaemenid Inscriptions. Minneapolis, MN: University of Minnesota Press.

McDonald, A. (2004). A botanical perspective on the identity of Soma (Nelumbo nucifera Gaertn.) based on scriptural and iconographic records. Economic Botany, 58(Suppl. Winter), S147-S173. doi:10.1663/0013-0001(2004)58[S147:ABPOTI] 2.0.CO;2

McKenna, T. (1992) [1984]. Food of the Gods. London, UK: Rider.

Modi, J. J. (1922). The religious ceremonies and customs of the Parsis. Mazagaon, Bombay: British India Press.

Mukherjee, B. L. (1921). The soma plant. Journal of the Royal Asiatic Society of Great Britain and Ireland, 2(April), 241-244. Retrieved from https:/www.jstor.org/stable/ i25209714

Nadkarni, K. M. (1954) [1908]. Indian Materia Medica (Vols. 1-2, 3rd ed.). Bombay/Panvel, India: Popular Book Depot/ Dhootapapeshwar Prakashan Ltd.
Naranjo, C. (1973). The healing journey: New approaches to consciousness. New York, NY: Ballantine Books.

Navet, É. (1988). Les Ojibway et l'Amanita tue-mouche (Amanita muscaria). Pour une ethnomycologie des indiens d'Amérique du Nord. Journal de la société des américanistes, 74(1), 163-180. doi:10.3406/jsa.1988.1334

Nigro, L., \& Spagnoli, F. (2018). Pomegranate (Punica granatulum L.) from Moyta and its deepest oriental roots. Vicino Oriente, XXII, 49-90. Retrieved from http://www.journalvo. it/Publicazioni/VO\%20XXII/VO_XXII_PDF_Autori/VO_ XXII_049-090_Nigro-Spagnoli.pdf

Noro, T., Miyase, T., Kuroyanagi, M., Ueno, A., \& Fukushima, S. (1983). Monoamine oxidase inhibitor from the rhizome of Kaempferia galanga L. Chemical and Pharmaceutical Bulletin, 31(8), 2708-2711. doi:10.1248/cpb.31. 2708

Nyberg, H. (1997). The problem of the Aryans and the Soma. In G. Erdosy (Ed.), The Indo-Aryans of ancient south Asia: Language, material culture and ethnicity (pp. 382-406). New Delhi, India: Munshiram Manoharlal.

O'Flaherty, W. D. (1969) [1968]. The post-vedic history of the Soma plant. In R. G. Wasson, Soma: Divine mushroom of immortality (pp. 95-147). New York, NY: Harcourt Brace Jovanovich, Inc.

Ott, J. (1996) [1993]. Pharmacotheon: Entheogenic drugs, their plant sources and history (2nd ed.). Kennewick, WA: Natural Products Co.

Ott, J. (1997). Pharmahuasca, ayahuasca and Vinho da Jurema: Human pharmacology of oral DMT plus harmine. Retrieved from http://ibogaine.mindvox.com/Articles/JO-Pharmahuasca. $\mathrm{htm}$. Accessed on: June 3, 2014 (Original work published in Yearbook of Ethnomedicine 1997/98).

Ott, J. (1998). The Post-Wasson history of the Soma plant. Eleusis (new series), 1, 9-37.

Ott, J. (2001). Applied psychonautics: Ayahuasca to pharmahuasca to anahuasca. Retrieved from http://ibogaine.mindvox. com/Articles/JO-AppliedPsychonautics.htm. Accessed on: June 3, 2014.

Ott, J. (2006). Análogos de la Ayahuasca: Enteógenos Pangeicos. Madrid, Spain: Ediciones Amargord.

Ott, J. (2011). Psychonautic uses of "Ayahuasca" and its analogues: Panacæa or Outré Entertainment. In B. C. Labate \& H. JungaberIe (Eds.), The internationalization of ayahuasca (pp. 105-122). Zürich, Switzerland/Berlin, Germany: LIT Verlag.

Padhy, S., \& Dash, S. K. (1997). Mushrooms as prohibited food in Manusmṛti vis-à-vis Amanita muscaria as Vedic soma plant. Ethnobotany, 9, 129.

Pandey, B. P. (1989). Sacred plants of India. New Delhi, India: Shree Publishing House.

Parker, R. C., \& Lux (2008). Psychoactive plants in tantric Buddhism: Cannabis and datura use in Indo-Tibetan Esoteric Buddhism. Erowid Extracts, 14(June), 6-11. Retrieved from https://www.scribd.com/doc/19943424/Psychoactive-Plants-inTantric-Buddhism-Cannabis-and-Datura-Use-in-Indo-TibetanEsoteric-Buddhism

Parpola, A. (2015). The roots of Hinduism: The early Aryans and the Indus Civilization. Oxford, UK/New York, NY: Oxford University Press.

Pendell, D. (2010) [2005]. Pharmako Gnosis: Plant teachers and the poison path. Berkeley, CA: North Atlantic Books. 
Pokras, R. S. (1991). The medical anthropology of the anti-aging soma and haoma of the Indian Samhitas. British Cactus and Succulent Journal, 9(4), 92-97.

Possehl, G. L. (2002). Indus-Mesopotamian trade: The record in the Indus. Iranica Antiqua, XXXXVII, 325-342.

Pramanick, D. D., Maiti, G. G., \& Srivastava, A. (2015). Micromorphological study of 'BALA' plant (Sida cordifolia L., Malvaceae) with special reference to its propagation technique. Journal of Medicinal Plant Studies, 3(4), 127-131. Retrieved from http://www.plantsjournal.com/archives/2015/vol3issue4/ PartB/3-3-35.pdf

Qazilbash, N. A. (1960). Ephedra of the Rigveda. The Pharmaceutical Journal, 26, 497-501.

Rahurkar, V. G. (1974). The use and control of liquor in Ancient India. Vishveshvaranand Indological Journal (Acharya Dr. Vishva Bandhu Commemoration Volume), XII(1 \& II), 286-300.

Rawala, G. S., Rawala, R., \& Sharma, M. P. (2002). Medicinally important agarics in Himalaya. In S. S. Samant, U. Dhar, \& M. S. Paini (Eds.), Himalayan medicinal plants: Potential and prospects (pp. 33-43). Nainital, India: Gyanodaya Prakashan.

Rohas-Aréchigas, M., \& Flores, J. (2016). An overview of cacti and the controversial peyote. In B. C. Labate \& C. Cavnar (Eds.), Peyote: History, tradition, politics, and conservation (pp. 21-42). Santa Barbara, CA/Denver, CO: Praeger.

Saar, M. (1991). Ethnomycological data from Siberia and northeast Asia on the effect of Amanita muscaria. Journal of Ethnopharmacology, 31(2), 157-173. doi:10.1016/03788741(91)90002-u

Saés, O. C. (2011). A vine network. In B. C. Labate \& H. Jungaberie (Eds.), The internationalization of ayahuasca (pp. 131-144). Zürich, Switzerland/Berlin, Germany: LIT Verlag.

Sarianidi, V. (1994). Temples of Bronze Age Margiana: Traditions of ritual architecture. Antiquity, 68(259), 388-397. doi:10. 1017/S0003598X00046731

Sarianidi, V. (1999). Near Eastern Aryans in Central Asia. The Journal of Indo-European Studies, $27(3 \& 4$, Fall/Winter), 295-326.

Sarianidi, V. (2003). Margiana and soma-haoma. Electronic Journal of Vedic Studies [EJVS], 9(1d).

Sarianidi, V. (2007). Necropolis of Gonur (I. Sarianidi, Trans.). Athens, Greece: Kapon Editions.

Schenk, G. (1956). The book of poisons (M. Bullock, Trans.). London, UK: Wiedenfeld and Nicholson.

Schultes, R. E. (1972). An overview of Hallucinogens in the Western Hemisphere. In P. T. Furst (Ed.), Flesh of the Gods: The ritual use of hallucinogens (pp. 3-54). New York, NY/ Washington: Praeger Publishers.

Schultes, R. E. (1977). The botanical and chemical distribution of hallucinogens. Journal of Psychedelic Drugs, 9(3), 247-263. doi:10.1146/annurev.pp.21.060170.003035

Schultes, R. E., \& Hoffman, A. (1980). The botany and chemistry of hallucinogens. Springfield, IL: Charles C. Thomas.

Schultes, R. E., Hoffman, A., \& Rätsch, C. (2001) [1979]. Plants of the Gods: Their sacred, healing, and hallucinogenic powers (2nd ed.). Rochester, VT: Healing Arts Press.

Shelley, W. S. (1995). The Elixir: An alchemical study of the ergot mushrooms. Notre Dame, IN: Cross Cultural Publications.

Shepard, G. (2005). Psychoactive botanicals in ritual, religion and shamanism. In E. Elizabetsky \& N. Etkin (Eds.), Ethnopharmacology: Encyclopedia of life support systems (EOLSS) (Vol.
2, Theme 6.79, pp. 128-182). Oxford, UK: UNESCO/Eolss Publishers.

Shepard, G. (2014). Will the real shaman please stand up?: The recent adoption of ayahuasca among indigenous groups of the Peruvian Amazon. In B. C. Labate \& C. Cavnar (Eds.), Ayahuasca shamanism in the Amazon and beyond (pp. 16-39). Oxford, UK/New York, NY: Oxford University Press.

Shulgin, A., \& Shulgin, A. (1997). TiHKAL: The continuation. Berkeley, CA: Transform Press.

Siklós, B. (1993). Datura rituals in the Vajramahabhairava Tantra. Curare, 188, 71-76.

Sinev, I. E. (2016). The history of Mandragora turkomanica (Solanaceae). Israel Journal of Plant Sciences, 63(3), 176-181. doi:10.1080/07929978.2016.1177956

Skjærvø, P. O. (2004). Smashing urine: On Yasna 45.10. In M. Stausberg (Ed.), Zoroastrian rituals in context (pp. 253-281). Leiden, The Netherlands/Boston, MA: E. J. Brill.

Smith, H. (1972). Wasson's Soma: A review article. Journal of the American Academy of Religion, 40(4) 480-499. doi:10.1093/ jaare1/XL.4.480

Spess, D. L. (2000). Soma: The divine hallucinogen. Rochester, VT: Park Street Press.

Srivastava, J. G. (1966). The Soma plant. Quarterly Journal of Crude Drug Research, 6(1), 811-818.

Staal, F. (2008). Discovering the Vedas: Origins, mantras, rituals, insights. New Delhi, India: Penguin Books.

Stuhrman, R. (1985). Worum handelt es sich beim Soma. IndoIranian Journal, 28(2), 85-93. doi:10.1007/BF00158055

Swamy, B. G. L. (1976). Sources for a history of plant sciences in India, II: The Rgveda Vedic Soma plant. Indian Journal of History of Science, 11(1), 11-32. Retrieved from https:// insa.nic.in/writereaddata/UpLoadedFiles/IJHS/Vol11_1_2_ BGLSwamy.pdf

Taillieu, D. (2012) [2003]. Haoma i. Botany. Encyclopcedia Iranica, XI(Fasc. 6), 659-662. Retrieved from http://www. iranicaonline.org/articles/haoma-i. Accessed on: August 19, 2018.

Thompson, G. (2003). Soma and ecstasy in the Rigveda. Electronic Journal of Vedic Studies [EJVS], 9(1e).

Thompson, G. (2007). On the Nāmarūpa of Soma. Nāmarūpa, 5, 65-69.

Toro, G., \& Thomas, B. (2007). Drugs of the dreaming, Oneirogens: Salvia Divinorum and other dream-enhancing plants. Rochester, VT: Park Street Press.

Trout, K. (2002) [1993-2001]. Trout's notes on some simple tryptamines: A brief overview \& resource compendium. Mydriatic Productions/Better Days Publishing.

Trout, K. (2004a). Trout's notes: Tryptamine content of Arundo donax. Retrieved from http://www.erowid.org/plants/arundo_ donax/arundo_donax_infol.shtml. Accessed on: October 30, 2014.

Trout, K. (2004b) [2002]. Trout's notes on the genus Desmodium (chemistry, ehnomedicine, pharmacology, synonyms and miscellany) (Trout's Notes D- 2). Austin, TX: Better Days Publications. Retrieved from http://troutsnotes.com/sc/ TNinfo.htm. Accessed on: October 22, 2014.

Waradpande, N. R. (1995). The Rgvedic Soma (Research Monograph II). Nagpur, India: Sanskrit Bhasha Pracharini Sabha.

Wasson, R. G. (1969) [1968]. Soma: Divine mushroom of immortality. New York, NY: Harcourt Brace Jovanovich, Inc. 
Wasson, R. G. (1971). The soma of the Rig Veda. What was it? Journal of the American Oriental Society, 91(2), 169-187. doi:10.2307/600096

Wasson, R. G., Kramrisch, S., Ott, J., \& Ruck, C. A. P. (1986). Persephone's Quest: Entheogens and the origins of religion. New Haven, CT/London, UK: Yale University Press.

Watkins, C. (1978). Let us now praise famous grains. Proceedings of the American Philosophical Society, 122(1), 9-17. Retrieved from https://www.jstor.org/stable/ i 240740
Windfuhr, G. L. (1985). Haoma/soma: The plant. In Papers in honour of Professor Mary Boyce (Acta Iranica 25, pp. 699-726). Leiden, The Netherlands: E. J. Brill.

Witzel, M. (2000). The home of the Aryans. In A. Hinze \& E. Tichy (Eds.), Anusantatyai: Festschrifft für Johanna Narten (Münchener Studien zur Sprachtwissenschafft, Beiheft 19, pp. 283-338). Dettelbach, Germany: J. H. Röll Verlag.

Witzel, M. (2003). Linguistic evidence for cultural exchange in prehistoric Western Central Asia. Sino-Platonic Papers, 129, 1-70. Retrieved from http://www.sino-platonic.org/complete/ spp129_prehistoric_central_asia_linguistics.pdf 